\title{
Insects and Spiders as Evidences for War Crimes and Torture
}

\author{
Aly H. Rasmy \\ National Research Centre, Dokki, Cairo, Egypt \\ email: aly_rasmy@hotmail.com
}

The applications of forensic entomology have proceeded so fast to overstep the use of insects and spiders in estimating the postmortem interval or cause of death. Therefore, it is interesting to incorporate insects and acarines in crime scene intelligence to uncover domestic crimes against humanity, through providing evidences of genocide, drugging, torture and even sexual assault prior to death. Moreover, insects can provide important information concerning the identification of explosive compounds and mass graves movement or postmortem movement of body.

It is of interest to note that the intelligence agencies, CIA and IC can learn valuable information from forensic entomology. When a body is found in a mass grave or a crime scene investigated, insects, acarines and spiders can provide answers to what happened, e.g. when, where and how someone was murdered and possibly who is the perpetrator or the murder.

\section{Torture}

Moreover, another area where forensic entomology could yield intelligence is evidence of torture. Insects can provide clues to what happened prior to death particularly during detention or severe questioning as many died with their hands bound. Consequently, they are incapable to avoid invasion of flies and scabies mites which may lay their eggs in the natural openings of the body or on the skin causing ulcers and myiasis. For example, scab, wound myiasis, ocular myiasis, aural myiasis, myiasis of nose, myiasis of rectal region. and vagina.

Such attack by insects and flies is evidence of cases of abuse (Genard, 2007 and Rasmy, 2008).

\section{Drug trafficking}

Starkeby (2004) reported that a brick of marijuana was shipped from Colombia to USA. The drug was seized at USA border. Laboratory investigation revealed that a spider species, recorded only in Coloribia was found associated with the drug. Therefore, this led investigators to know where the drug came from and produced.

\section{Rape}

In this concept, when a highly decomposed female body is examined for evidence of rape, semen samples are usually not available. But, maggots taken from the vaginal area can reveal if the woman was sexually assaulted as the seminal DNA of the perpetrator can be passed to maggots through feeding (Cruz, 2006).

\section{Deceptive mass graves movement}

Insect evidence may provide clues as if a body was moved or relocated after death. Deceptive mass graves movement included victims or defeated soldiers as a murder victim transported to another location may have signs consisted only with the original because different insect species have different habitat preference and may differ from country to another (Barenbaum, 1985).

\section{Explosive compounds detection}

In this regard, insects would be able to allow intelligence analyst to identify and detect explosive compounds used in terrorist bombings, by chemical analysis of arthropods found on the body of victims when other means of identification are not available. This is plausible because these arthropods eat the dermal tissue, while the body of victims decomposes; drugs or explosives break down into the tissues and degraded. Thus makes the corpse to be unsuitable for toxicological analysis. Therefore, the only witness for analysis involving war crimes or terrorist activities is the blowfly larvae.

Also, in this concept, a Korean aircraft was shot down in 1983 by Soviet air to air missile after it had strayed into Soviet air space. Maggot samples collected from the previous bombing victims submitted to chemical analysis test positive to TNT. Thus, it was determined that the cause of plane crash was due to foul play and not due to mechanical failure (after Cruz, 2006). 


\section{Case of deception}

A badly decomposed body was found in a saltwater tank in Azerbaijan, 1962. Laboratory studies on live fly larvae found on the body revealed that they could not survive in saltwater. Thus, proving that the body had been in the tank for only a short time. This indicated that the death had occurred at another location, and thereafter, the corpse had been placed in the tank (Starkeby, 2004).

In closing, the cases discussed reveal that forensic entomology/ acarology shed light on the criminal act that being hidden by a specific person or force.

\section{REFERENCES}

Cruz, A.M. 2006. Crime scene intelligence: An experiment in forensic entomology. The National Defence Intelligence College Press, 73 pp.

Barenbaum, M.R. 1985. Ninety-nine more maggots, mites and munches. Urban and Chicago: University of Illinois Press, 10-46.

Gennard, D.E. 2007. Forensic entomology: An introduction. Jon Wiley and Sons Ltd, England. 244 pp.

Rasmy, A.H. 2008. Mites and insects as indicators of physical abuse. Acarines, 2: 1-2.

Rasmy, A.H. 2010. Entomological and ecological evidence of bloodstain patterns in forensic investigation. Acarines, 5: 1-2.

Starkeby, M. 2004. Ultimate guide to forensic entomology: Introduction to forensic entomology. Web only essay. URL. Accessed. 5 January 2004. 